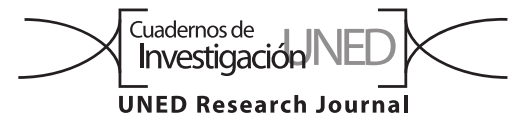

\title{
A leucistic female Canis latrans (Carnivora: Canidae) in Costa Rica
}

\section{Stephanny Arroyo-Arce ${ }^{1,2^{*}}$, Daniel Corrales-Gutiérrez ${ }^{1}$, Deiver Espinoza-Muñoz', Daniela Araya-Gamboa', Mónica Chávez-Ramos' ${ }^{1}$ \& Roberto Salom-Pérez ${ }^{1}$}

1. Panthera, San Pedro de Montes de Oca, San José, Costa Rica;

sarroyo@panthera.org, (D) https://orcid.org/0000-0003-0993-0071, dcorrales@panthera.org, (iD https://orcid.org/0000-0002-7493-3490, despinoza@panthera.org, (iD https://orcid.org/0000-0002-5925-3729, daraya@panthera.org, (iD https://orcid.org/0000-0002-9622-517X, mchavez@panthera.org, (iD https://orcid.org/0000-0002-8187-8346

2. Coastal Jaguar Conservation, 126-3100, Santo Domingo, Heredia, Costa Rica; rsalom@panthera.org, (iD https://orcid.org/0000-0003-3404-9585

* Correspondence

Received 11-IX-2019 • Corrected 01-XII-2019 • Accepted 02-XII-2019

DOI: https://doi.org/10.22458/urj.v11i3.2618

ABSTRACT: Partial depigmentation (leucism) is rare in mammals. We report 17 camera trap records of a single female leucistic coyote (Canis latrans) in Costa Rica between 2014 and 2018.

Key words: coyote, mammal, leucism, camera trap, Costa Rica.
RESUMEN: "Hembra de Canis latrans (Carnivora: Canidae) in Costa Rica". La despigmentación parcial (leucismo) es poco común en mamíferos. Aquí reportamos un total de 17 registros fotográficos de una hembra leucística de coyote (Canis latrans) en Costa Rica entre 2014 y 2018.

Palabras clave: coyote, mamífero, leucismo, cámara trampa, Costa Rica.
The coyote (Canis latrans) is a canid with a geographic distribution ranging from Alaska to western Panama (Wainwright, 2007). In Costa Rica, it is associated with both open (e.g. dry forest, paramo), and disturbed habitats (e.g. agricultural lands, areas near small towns) and primarily at elevations below $3400 \mathrm{~m}$ (Wainwright, 2007; Wilson \& Mittermeier, 2009). Coyote coloration ranges from gray to rufous, with darker and grayer colorations more common at higher latitudes (Bekoff, 1977; Wilson \& Mittermeier, 2009). Melanistic coyotes are rare (Gipson, 1976; Wilson \& Mittermeier, 2009) while albino and leucistic (e.g. partially depigmented) coyote reports are even scarcer (Johnston, 1930; Young, 1951; LópezGonzález, 2011). Herein, we document the first evidence of a leucistic coyote in Costa Rica.

The study area encompasses the western boundary of Cordillera Volcánica Central Forest Reserve and
Barbilla-Destierro Biological Subcorridor (Fig. 1). This area is characterized by a wide altitudinal gradient, with elevations ranging from $75 \mathrm{~m}$ up to $3340 \mathrm{~m}$ (Bolaños \& Watson, 1993; Panthera, 2015). The main economic activities are livestock, agriculture and tourism (Panthera, 2015).

As part of a mammal monitoring research project, from August 25, 2014 to April 23, 2015 a total of 52 camera traps (PANTHERA V3, V4, V5) stations were located across Cordillera Volcánica Central Forest Reserve (for a total of 3495 camera trap nights). Additionally, a total of 90 camera trap stations were located in BarbillaDestierro Biological Subcorridor from August 29, 2017 to August 02, 2018 (for a total of 9041 camera trap nights) (Fig. 1). A total of 17 occurrences of a white coyote were recorded at three locations approximately $1 \mathrm{~km}$ apart (Table 1). All these records correspond to what appears to be the same adult female, characterized by her white 

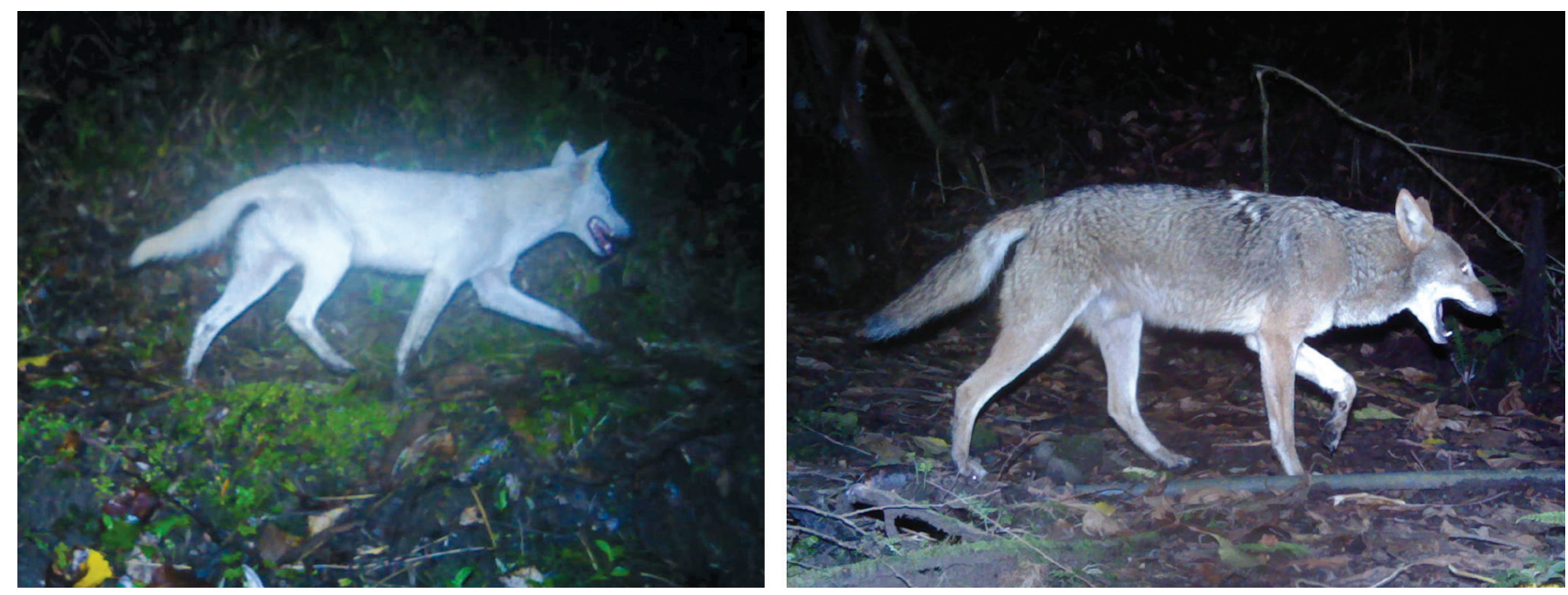

Fig. 1. Records of a leucistic coyote across the study area, Costa Rica.

TABLE 1

Occurrence events of a female leucistic coyote (Canis latrans)

in Cordillera Volcánica Central Forest Reserve and Barbilla-Destierro Biological Subcorridor, Costa Rica

\begin{tabular}{cccc} 
Camera trap & Date & Time & Coordinates (N \& W) \\
Station 02 & April 01, 2015 & $5: 35$ & $10,038825 \&-83,724521$ \\
Station 03 & March 30, 2015 & $22: 55$ & $10,037004 \&-83,732208$ \\
Station 03 & March 31, 2015 & $23: 04$ & $10,037004 \&-83,732208$ \\
Station 01 & September 06, 2017 & $16: 55$ & $10,040437 \&-83,721807$ \\
Station 01 & September 08, 2017 & $20: 10$ & $10,040437 \&-83,721807$ \\
Station 01 & September 17, 2017 & $21: 40$ & $10,040437 \&-83,721807$ \\
Station 01 & September 18, 2017 & $13: 22$ & $10,040437 \&-83,721807$ \\
Station 01 & September 24, 2017 & $3: 25$ & $10,040437 \&-83,721807$ \\
Station 01 & September 24, 2017 & $21: 51$ & $10,040437 \&-83,721807$ \\
Station 01 & September 24, 2017 & $22: 09$ & $10,040437 \&-83,721807$ \\
Station 01 & December 03, 2017 & $10: 18$ & $10,040437 \&-83,721807$ \\
Station 01 & December 11, 2017 & $22: 48$ & $10,040437 \&-83,721807$ \\
Station 01 & December 13, 2017 & $4: 35$ & $10,040437 \&-83,721807$ \\
Station 01 & January 02, 2018 & $10,040437 \&-83,721807$ \\
Station 01 & January 05, 2018 & $15: 53$ & $10,040437 \&-83,721807$ \\
Station 01 & January 06, 2018 & $1: 34$ & $10,040437 \&-83,721807$ \\
Station 01 & January 07, 2018 & $2: 44$ & $10,040437 \&-83,721807$ \\
\hline
\end{tabular}

fur with a slight rufous coloration across her body (Fig. 2). The authors consider it to be a leucistic individual due to the partial depigmentation of the fur and normal coloration of the eyes, which is consistent with Jehl (1985). Albino individuals, on the other hand, are completely white and their eyes are red or blue (Hu, Hanifin, Prescott, \& Tongue, 1980).

Abnormal colorations in wild populations of coyotes are extremely rare. For instance, in the United States,
Johnston (1930) mentioned just one albino coyote out of 20000 individuals, while Young (1951) reported that in 30 years, one out of 287767 individuals were albino. More recently, López-González (2011) documented one leucistic coyote in the Chihuahuan Desert of Durango, México. It is still unclear what factors trigger this condition in the wild. However, some authors (Bensch, Hansson, Hasselquist, \& Nielsen, 2000; Brito \& Valdivieso-Bermeo, 2016) linked leucism to inbreeding (e.g. due to isolation 


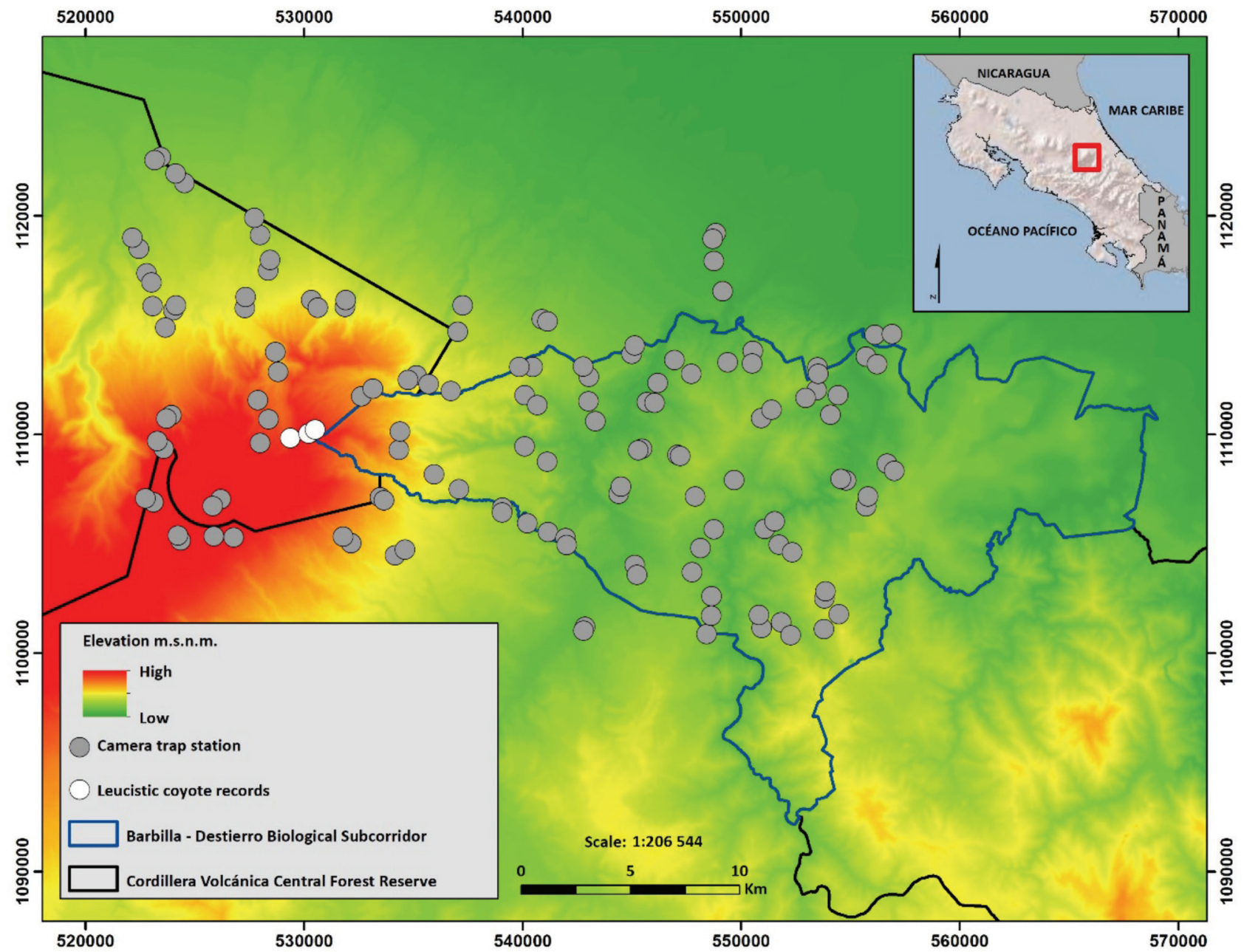

Fig. 2. Camera trap photos of coyotes (Canis latrans) recorded in the study area, Costa Rica. Above: a leucistic coyote; below: a coyote with standard coloration.

of populations), heritable mutation (van Grouwn, 2013) and environmental factors (e.g. nuclear pollution; Moller \& Mousseau, 2001). Regardless of the cause, it could be assumed that the lack of pigmentation on coyotes, and on most other wild species, could represent an ecological disadvantage in the Tropics. For example, their inability to camouflage could decrease their hunting success and make them an easier target for sympatric predators (e.g. Panthera onca, Puma concolor). Furthermore, it could also reduce an individual's breeding success, as well as its communication and thermoregulation (Caro, 2005). In conclusion, it is important for researchers to document occurrences of unusual colorations in wildlife to gain a better understanding of this condition.

Ethical, conflict of interest and financial statements: The authors declare that they have fully complied with all pertinent ethical and legal requirements, both during the study and in the production of the manuscript; that there are no conflicts of interest of any kind; that all financial sources are fully and clearly stated in the acknowledgements section; and that they fully agree with the final edited version of the article. A signed document has been filed in the journal archives.

\section{ACKNOWLEDGMENTS}

We would like to thank the Sistema Nacional de Áreas de Conservación (SINAC) of Costa Rica, the Costa Rican Electricity Institute (ICE) and landowners for giving us permission to conduct this work and for their logistical support. We would also like to thank the BarbillaDestierro Biological Subcorridor Local Council and all the 
assistants and guides that helped in this study, specially to Ever Urbina Ruiz. Funding for this project was provided by the Interamerican Development Bank and Panthera.

\section{REFERENCES}

Bensch, S., Hansson, B., Hasselquist, D., \& Nielsen, B. (2000). Partial albinism in a semi-isolated population of Great Reed Warblers. Hereditas, 133, 167-170. DOI: 10.1111/ j.1601-5223.2000.t01-1-00167.x

Bekoff, M. (1977). Canis latrans. Mammalian Species, 79, 1-9. DOI: $10.2307 / 3503817$

Bolaños, R., \& Watson, V. (1993). Mapa Ecológico de Costa Rica, según el sistema de clasificación de Zonas de Vida del Mundo de L. R. Holdridge (Escala: 1:200 000). San José, Costa Rica: Centro Científico Tropical.

Brito, J., \&Valdivieso-Bermeo, K. (2016). First records of leucism in eight species of small mammals (Mammalia: Rodentia). Therya, 7, 483-489. DOI: 10.12933/therya-16-408

Caro, T. (2005). The adaptive significance of coloration in mammals. Bioscience, 55, 125-136. DOI: 10.1641/0006-3568(2005)055[0125:TASOCI]2.0.CO;2

Gipson, P. (1976). Melanistic Canis in Arkansas. The Southwestern Naturalist, 21,124 . DOI: 10.2307/3670332

Hu, F., Hanifin, J. M., Prescott, G. H., \& Tongue, A. C. (1980). Yellow mutant albinism: Cytochemical ultrasturcutal and genetic characterization suggesting multiple allelism. American Journal of Human Genetics, 32, 387-395.
Jehl, J. R. (1985). Leucism in eared grebes in western North America. The Condor, 87, 439-441. DOI: 10.2307/1367236

Johnston, A. (1930). Color in the Animal Kingdom. Bios, 1, 28-38.

López-González, C. A. (2011). Registro de un coyote (Canis latrans) blanco en el desierto chihuahuense de Durango, México. Acta Zoológica Mexicana, 27, 871-873. DOI: 10.21829/azm.2011.273791

Moller, A. P., \& Mousseau, T. A. (2001). Albinism and phenotype of barn swallows. Evolution, 55, 2097-2104. DOI: 10.1111/j.0014-3820.2001.tb01324.x

Panthera. (2015). Programa de monitoreo de mamíferos medianos y grandes en el Subcorredor Biológico BarbillaDestierro/Paso del Jaguar. Informe Final. San Pedro, San José: Panthera-Costa Rica.

van Grouw, H. (2013). What colour is that bird? British Birds, 106, 17-29.

Wainwright, M. (2007). The mammals of Costa Rica: a natural history and field guide. Ithaca, New York, and London, United Kingdom: Zona Tropical, Comstock Publishing Associates, Cornell University Press.

Wilson, D. E., \& Mittermeier, R. A. (2009). Handbook of the Mammals of the World. Vol. 1. Carnivores. Barcelona, Spain: Lynx Editions.

Young, S. P. (1951). The clever coyote: its history, life, habits economic status and control. Nebraska, USA: University of Nebraska Press. 